\title{
Memes no meio digital: um olhar teórico sobre sua propagação nas redes sociais
}

DOI: http://dx.doi.org/10.21165/el.v48i2.2337

\section{Sergio Mikio Kobayashi ${ }^{1}$}

\section{Resumo}

Este artigo discute uma perspectiva teórica sobre os Memes da internet e realiza uma análise ilustrativa a partir desta formulação. Para isso, percorremos um caminho teórico das noções básicas a respeito da constituição do Meme, desde sua concepção biológica até sua inserção nos meios digitais, nos apoiando principalmente nas contribuições de Richard Dawkins (1979) e Limor Shifman (2013). Em seguida, realizamos uma análise experimental do Meme "Senhora", observando as categorias de concorrência, variação, retenção e seleção que a autora defende. Desta maneira, pudemos observar os aspectos dialógicos e de variação necessários para a conformação de um Meme e sua análise inserida em uma cadeia de gêneros.

Palavras-chave: meme; mídia digital; redes sociais.

1 Universidade de São Paulo (USP), São Paulo, São Paulo, Brasil; kobayashisergio@gmail.com; https://orcid.org/0000-0002-8987-2811 
Memes on Digital Media: a Theoretical Approaching on its Spreading Through the Web

\begin{abstract}
This article discusses a theoretical perspective on the Memes from the internet and proposes an illustrative analysis from this formulation. For this, we used the basic notions about the constitution of Meme as a theoretical subsidy, from its biological conception to its insertion in the digital media, supporting ourselves mainly on the contributions of Richard Dawkins (1979) and Limor Shifman (2013). Then, an experimental analysis of the Meme "Senhora" was developed, focusing on the categories of competition, variation, retention and selection defended by the author. Finally, the dialogical and variation aspects necessary for the conformation of a Meme and its analysis inserted in a chain of genre were observed.
\end{abstract}

Keywords: meme; digital media; social media.

\title{
Introdução
}

Este artigo tem por objetivo promover uma reflexão teórica a respeito do gênero Meme, de modo a caracterizar as especificidades que o constituem no meio digital, sobretudo em redes sociais no Brasil. Para isso, mobilizamos os pressupostos de Shifman (2013) sobre o Meme Digital, a fim de apresentar seu funcionamento na realidade brasileira, a partir de uma breve análise do Meme "Senhora". Para sustentar a teoria da referida autora, propomos, também, um diálogo mínimo com a perspectiva de Dawkins (1979) e com um levantamento histórico da interação ${ }^{2}$ na internet.

A escolha deste objeto se deu por conta das condições cada vez mais dinâmicas que a linguagem tem encontrado no meio digital, fazendo com que se modifique e se expresse em gêneros mais complexos. Segundo dados de 2015 do Instituto Brasileiro de Geografia e Estatística (IBGE, 2015), os brasileiros na internet superam 100 milhões de usuários, representando mais de $50 \%$ da população; isso significa que o meio digital está se tornando, gradativamente, uma ferramenta indispensável para a comunicação e transmissão de ideias.

Nessa perspectiva, a disseminação e inserção de conteúdo, de polêmicas do cotidiano e trivialidades até debates políticos e sociais estão cada vez mais recorrentes e rápidas. As redes sociais permitem uma ação mais responsiva e imediata, de modo a condensar diferentes informações e pontos de vista em um meio dinâmico e acessível. Assim, um

2 Interagir, aqui, deve ser compreendido em um sentido amplo, o que inclui a troca de mensagens entre usuários e o contato com diversos textos, de caráter informativo ou opinativo, que circulam pela rede. 
determinado conteúdo que, antes do advento da internet, demoraria dias ou semanas para ser disseminado, pode viralizar em todo o mundo em questão de minutos. Como este veículo não possui mão única tal qual as mídias tradicionais, isto é, é conceptualmente interacional, permite que a disseminação de uma ideia ou conteúdo seja constantemente afetada por outros discursos que circulam nesta rede.

O gênero Meme surge a partir destas condições fornecidas pelas redes sociais, tornandose um importante modo de condensar diversos conteúdos e discursos de maneira sucinta, como veremos adiante neste artigo. Por conta desta importância, se faz necessária uma elaboração teórica adequada ao referido gênero. Uma vez que o uso do meio digital como alternativa de interação social ainda é um evento recente, o estudo linguístico, textual e discursivo deste campo da atividade humana carece de exploração. Acreditamos que tal formulação contribuirá para os estudos linguísticos e discursivos deste fenômeno.

Para dar conta de realizar esta proposição teórica, dividimos este trabalho em dois momentos distintos: o primeiro discute as redes sociais de comunicação na internet de modo amplo, a fim de contextualizar o gênero discursivo em questão, retomando brevemente um histórico das redes sociais no Brasil. Por fim, apresentaremos uma análise ilustrativa que tem por objetivo verificar os conceitos de concorrência, variação, seleção e retenção de Shifman (2013) no Meme "Senhora". Para isso, coletamos quatro instâncias deste Meme que nos auxiliam na discussão destas características propostas pela autora.

\section{Redes Sociais de Comunicação}

A partir da popularização da internet, as informações passaram a circular com uma velocidade até então inimaginável: em poucos minutos, uma informação pode viralizar em todo o mundo. Por conta disso e do avanço tecnológico, novas possibilidades de uso e combinação de distintas modalidades semióticas - verbal, pictórica, sonora, dentre outras - foram desenvolvidas, o que levou a mudanças nas práticas discursivas - seja em termos de produção, de distribuição, de consumo e de interpretação e textos (cf. CASTELLS, 2015). Nesse sentido, essa transformação também significou a necessidade de uma readaptação por parte dos atores sociais, que passaram a interagir por intermédio de uma máquina conectada a uma rede global de computadores.

Essa revolução tecnológica e comunicativa não resultou, no entanto, na dizimação ou eliminação dos antigos modos de agir e interagir. Chamamos a atenção para o que nos aponta Bakhtin (1993) sobre os gêneros possuírem um campo de existência (seu cronotopo) e surgirem sem necessariamente suprimir outros gêneros. Dessa maneira, os gêneros discursivos no meio digital incorporaram características de outros gêneros, de maneira a adaptar-se a esse novo suporte, sem fazer com que aqueles deixassem de 
existir3: a carta pessoal que embasou a constituição do e-mail, a conversa cotidiana que inspirou os chats e bate-papos, os diários pessoais que deram origem ao blog etc.

Essas práticas discursivas, a partir das mudanças advindas deste novo suporte, passaram a ter um caráter ainda mais dinâmico e dialógico. Ora, se antes os enunciados que se interligavam entre si já eram altamente responsivos (cf. BAKHTIN, 2003), com o surgimento de uma linguagem tecnológica que permite, dentre outras coisas, responder diretamente, curtir, compartilhar, copiar e colar, as formas de comunicação tornaram-se ainda mais complexas.

Também é possível notar mudanças no comportamento linguístico por conta destes novos gêneros discursivos, do aspecto lexical ao semântico, em que as estratégias de remissão a enunciados anteriores são transformadas, já que frequentemente os textos estão todos nesta rede digital. A própria criação de hiperlinks e opções como "assuntos relacionados" são fatores fundamentais para a constituição destas mudanças linguísticas nos textos digitais. Nesse sentido, Elias (2014, p. 47, grifo da autora) defende que

[A] conectividade, concretizada na atualização de links, possibilita ao hipertexto a sua constituição em rede, a sua expansão reticular. Nessa configuração, o leitor é sempre convidado a "saltar" do ponto em que se encontra para outros pontos do universo hipertextual, bastando tão somente ativar os links, elementos que possibilitam o acesso a textos em várias linguagens e mídias, promovendo novos modelos de produção e consumo de texto.

Quando tratamos, contudo, de internet, sobretudo nos dias atuais, devemos fazer al gumas ponderações com relação à maneira com que ela viabiliza tais mudanças na forma com que as pessoas interagem no mundo, levando em consideração seu histórico, haja vista que, se uma rede mundial interconectada digitalmente já foi um processo revolucionário, o surgimento e estabelecimento de redes sociais mais dinâmicas significou uma segunda revolução na maneira de interagir.

Diversos autores (CASTELLS, 2015; SHIFMAN, 2013; SOUZA-JUNIOR, 2013; KOBAYASHI, 2017) defendem que o surgimento das redes sociais tornou complexas as relações da internet. No princípio de seu uso comercial - quando deixou de ser uma ferramenta de compartilhamento de dados de empresas, governos e universidades -, isto é, a partir de sua comercialização como um produto no final dos anos de 1980 e início de 1990, a rede digital tinha como principais funções a troca de e-mails, partilha de conhecimento em

3 Não nos cabe, nem interessa, aqui, debater em que medida a conformação de novos gêneros digitais diminuiu ou aumentou a importância dos gêneros tradicionais. 
sites e, com o passar do tempo, surgiram ferramentas de comunicação direta instantânea através de bate-papos públicos ou privados (MIRC, ICQ, MSN Messenger). Nesse período, a comunicação era predominantemente verbal, isto é, com velocidade limitada, recursos tecnológicos ainda raros e caros; outras semioses não eram comumente encontradas nas interações entre os usuários.

Já no final dos anos 1990 e início dos anos 2000, a internet - que se tornava cada vez mais um produto atrativo - passou a contar com mais velocidade, através da conexão de banda larga (alta velocidade). Essa evolução possibilitou o surgimento e a rápida popularização de plataformas com uma maior diversidade de ferramentas de interação e compartilhamento de ideias, dentre as quais redes sociais como o Facebook (2004), Orkut (2004) e Twitter (2006).

O estabelecimento dessas redes sociais, conjuntamente com a constante evolução tecnológica (popularização de smartphones, dados móveis de internet, câmeras fotográficas, ampliação do armazenamento de dispositivos etc.), exacerbou o caráter de instantaneidade das ações na internet: uma foto de uma pessoa pública em uma situação constrangedora pode ser tirada e, em segundos, tornar-se notícia de uma revista, que vai receber comentários e compartilhamentos e, assim, uma grande e complexa rede passa a ser constituída; um estudante que se esqueceu de estudar para a prova pode baixar o livro e lê-lo durante o percurso até a faculdade no ônibus; o empresário pode realizar um empréstimo em um banco sem sair de casa; os avós que moram no Brasil podem acompanhar, em tempo real, o nascimento do neto no Japão etc.

Este segundo momento da internet, que trouxe a instantaneidade às relações e práticas sociais, denomina-se Web 2.04 (cf. SHIFMAN, 2013).

\subsection{Memes: de Dawkins à Era Digital}

Dentro das novas relações constituídas pela internet (tanto em seus primórdios quanto na era 2.0), surge o Meme digital. O termo "Meme" foi cunhado pelo biólogo Richard Dawkins (1979) como uma unidade de informação transmitida por meio de compartilhamento de informações, seja de pessoa para pessoa ou mesmo por suportes de transmissão, como livros, rituais, crenças, tradições etc. O termo deriva do conceito biológico de gene como um replicador. Para Dawkins, os memes são unidades culturais que se replicam e se autopropagam através do tempo. $\mathrm{O}$ autor aponta para três características fundamentais para a constituição de um Meme: fidelidade, longevidade e fecundidade.

4 Web 2.0 é um termo genérico que causa controvérsias entre os autores que estudamos. Não iremos nos ater a esta diferença, portanto, utilizaremos a perspectiva de Shifman (2013) indiscriminadamente. Para a autora, o termo se refere ao segundo momento da internet que discutimos, constituído a partir do estabelecimento das Redes Sociais. 
A concepção de fidelidade gira em torno da necessidade de um Meme se manter fiel ao que o originou, ou seja, transmitir fielmente uma ideia como uma forma de herança cultural ou social; já a longevidade diz respeito à extensão da vida do meme, que não deve ser curta; por fim, a fecundidade é a capacidade de se replicar e se espalhar. Souza Júnior (2013), baseando-se nessa noção de Dawkins, traz o exemplo de "Fé e Natal como celebração do nascimento de Jesus" como forma de aplicar esses três conceitos. De acordo com o autor, este Meme, dentro da concepção de Dawkins, é fiel, pois pode ser transmitido, sem ruídos, de preferência, de pai para filho, da igreja para o fiel etc. É fecundo, pois pode ser transmitido, de modo a permanecer fiel ao propósito original, por diversos canais específicos, como retórica bíblica, oração, ou qualquer outra prática que seja necessária. É longevo, pois, no ocidente, ainda é vigente em práticas, como o calendário cristão.

Devido à escassa literatura sobre este gênero quando assume uma forma digital, uma vez que começou a ser utilizado de modo massivo apenas a partir desta década, data de 2013 uma das primeiras discussões aprofundadas sobre a problemática. Trata-se da obra Memes in a digital culture, de Limor Shifman (2013). Baseando-se, dentre outras fontes, na perspectiva de Dawkins que apresentamos, a autora defende que, inicialmente, o termo Meme foi lançado para designar ocorrências em outras esferas da vida, como "melodias, frases de efeito e modas de vestuário" (SHIFMAN, 2013, p. 9, tradução nossa) ${ }^{5}$. Quando, na década de 1970, o autor britânico teoriza a respeito da noção, a internet estava longe de ser um bem de consumo de massas, assim, as estruturas meméticas (ou Memes) já eram um conceito que circulava antes da reprodução dos meios digitais.

Desse modo, para constituirmos um percurso histórico do Meme na era digital, devemos considerar os primeiros passos da internet enquanto produto comercial. Como debatemos na seção anterior, em dado período inicial da Web, a comunicação era majoritariamente verbal, com poucos recursos multimodais nas interações. Jablonka (2012, p. 111, grifos da autora) defende que a demanda por sinais não verbais - importantes para a comunicação interpessoal, segundo a autora - fez com que surgisse "algo que pudesse completar e preencher as lacunas existentes. [...] Esta função no início foi assumida por emoticons". Emoticon é uma palavra em inglês que surgiu pela junção das palavras emotion (emoção) e icon (ícone).

Essa forma de comunicação passou a ser representada, inicialmente, por uma combinação de caracteres como :-), :-(, :-D, :-P ${ }^{6}$ e, posteriormente, os próprios suportes de interação passaram a incorporar esse recurso através da transformação dos símbolos em imagens pré-estabelecidas (Figura 1). Com o passar do tempo, outras formas de uso de emoticons foram desenvolvidas. Mencionamos o MSN Messenger que, em meados

\footnotetext{
5 No original: "melodies, catchphrases, and clothig fashions".

6 Respectivamente representam: Rosto Feliz, Rosto Triste, Rosto Sorrindo, Mostrando a Língua.
} 
dos anos 2000, permitiu que os usuários passassem a "criar" emoticons inserindo um gif7 a um determinado código, o que possibilitava que diversos tipos de "reações" pudessem ser transmitidos.

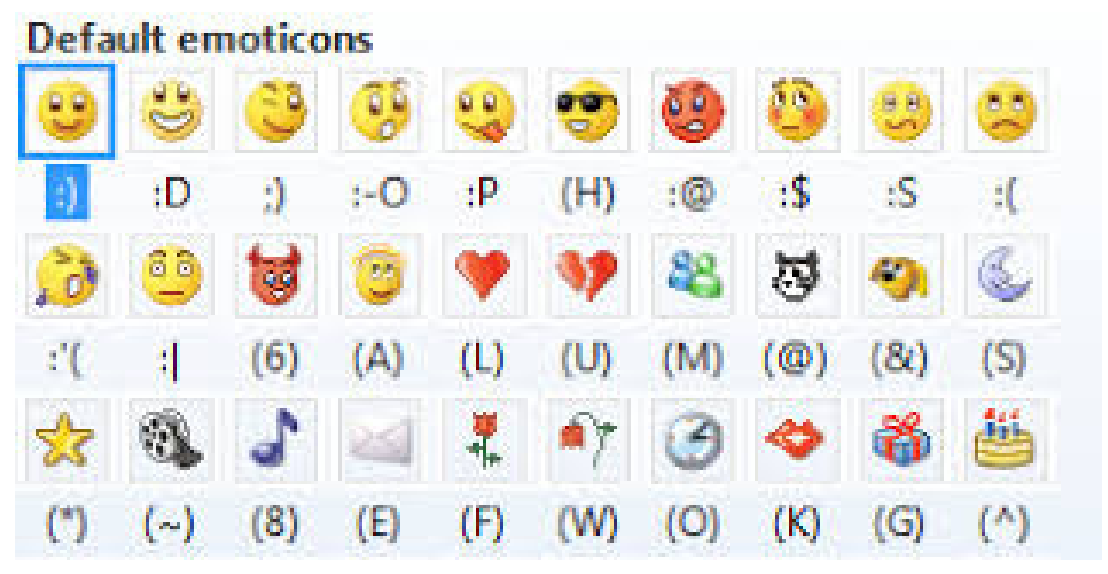

Figura 1. Emoticons do MSN Messenger

Fonte: forums.malwarebytes.com/topic/33765-default-msn-messenger-emoticons. Acesso em: 17 jun. 2018.

Dentre as múltiplas formas de se expressar nesses espaços, surgiu um conjunto de expressões caricaturais, formada por caracteres, como os emoticons de outrora, que representava (ou levava a interpretar) determinadas reações humanas (cf. KOBAYASHI, 2017). Podemos incluir, nesse rol, os clássicos "Lenny Faces" (Figura 2):

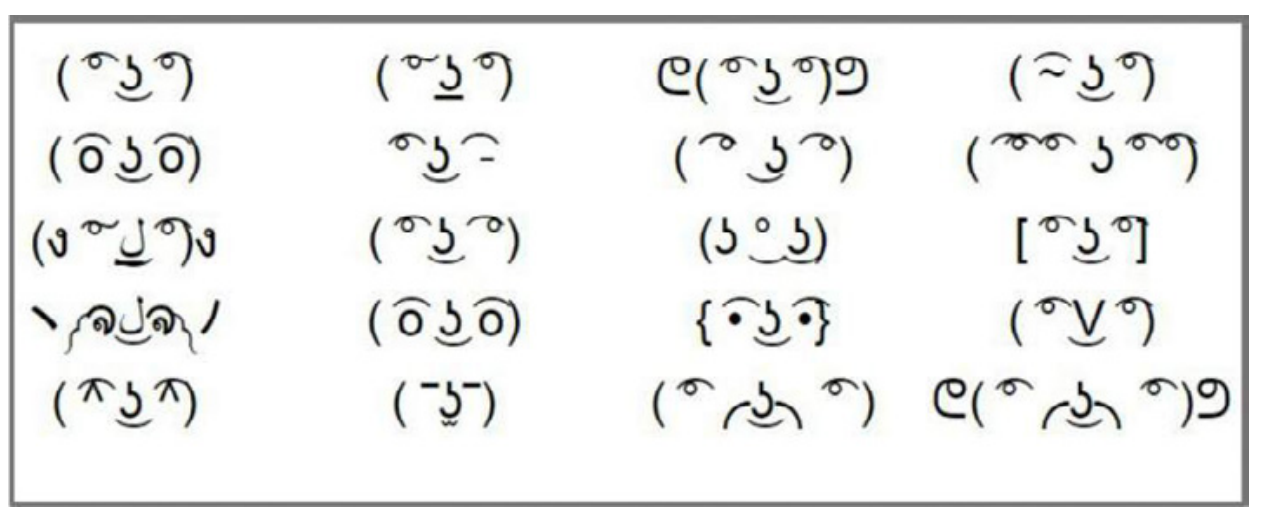

Figura 2. Lenny Faces

Fonte: http://hacktheplanetbook.com/6518. Acesso em: 17 jun. 2018.

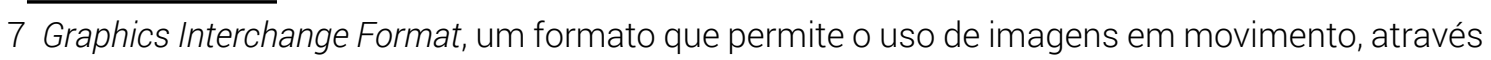
da apresentação de imagens em sequência. 
Com as novas formas de representar essas expressões, o termo emoticon caiu em desuso entre os usuários ocidentais, que passaram a se referir a este conjunto de imagens como emoji, termo originário do Japão, que englobava um conjunto maior de figuras prontas. Com a expansão do conceito e das possibilidades de uso, logo as "Lenny Faces" passaram a ser referidas ora como emoji, ora como Meme ${ }^{8}$. Não se sabe ao certo como este conceito surgiu nas redes sociais, mas é a partir dessas manifestações que o termo passou a ser utilizado, uma vez que exprimia uma ampla possibilidade de interpretações nos mais variados contextos, como vemos na Figura 3 :

\section{$(50)$ Você (0.50) disse \\ $(0-50)$ de graça?}

Figura 3. Lenny Faces em Meme

Fonte: https://bit.ly/2LCNC8V. Acesso em: 17 jun. 2018.

O termo Meme passou a ganhar mais força e mais adesão nas redes sociais a partir da disseminação do "Troll Face" (Figura 4), advindo de uma tirinha publicada na comunidade "devianART". O uso dessa imagem passou a designar contextos de trollagem ${ }^{9}$ na internet, isto é, uma prática discursiva de desestabilização da interação ou dos participantes por meio de ofensa e desinformação. A transposição dessa imagem para contextos que não eram mais os da tirinha, a partir de uma abstração da noção de trollagem, passou a ser chamada de Meme em conjunto com outras caricaturas semelhantes, cada uma expressando algo diferente ${ }^{10}$.

8 Não temos por objetivo debater os limites entre o conceito de emoji e Meme neste trabalho.

9 Origem em Trolls, figuras monstruosas da mitologia nórdica (cf. OLIVEIRA, 2017).

10 Trouxemos o exemplo da Troll Face por ter sido uma das mais conhecidas e antigas representações do Meme. 


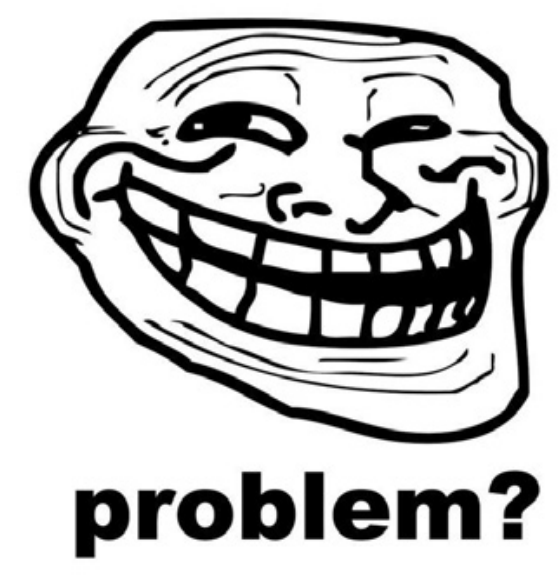

Figura 4. Troll Face

Fonte: https://knowyourmeme.com/memes/trollface-coolface-problem. Acesso em: 17 jun. 2018.

\section{Meme Digital: A teoria de Shifman}

Com a evolução das redes sociais e das tecnologias que debatemos, o Meme passou a acompanhar essas mudanças, de modo a poder ser constituído a partir de diversas outras possibilidades que não caricaturas, emojis e afıns. Ora, se a simultaneidade proporcionada por essa evolução digital permite a criação de redes cada vez mais complexas de comunicação digital, a possibilidade de variação de determinada semiose passa a ser maior. No Brasil, por exemplo, quando se instituiu o YouTube, um dos vídeos mais acessados foi o chamado "Sanduíche-iche"11, que se tratava de Ruth Lemos, uma nutricionista gaguejando, atrapalhada pelo ponto de retorno, em uma entrevista. Tão logo sua imagem foi remetida a diversos outros contextos, perdurando, em menor escala, até hoje (figura 5). Isso significa, portanto, que as possibilidades advindas da Web 2.0 também transformaram a produção, a distribuição e o consumo dos Memes. Por conta dessas e outras razões que traremos nesta seção, faz-se necessária uma abordagem que leve em consideração as características das redes sociais tal qual debatemos.

11 Disponível em: https://www.youtube.com/watch?v=pmn-dbBpglU. Acesso em: 17 abr. 2018. 
\#RuthLemosAnalisa

BRASIL 1 X 7 ALEMANHA

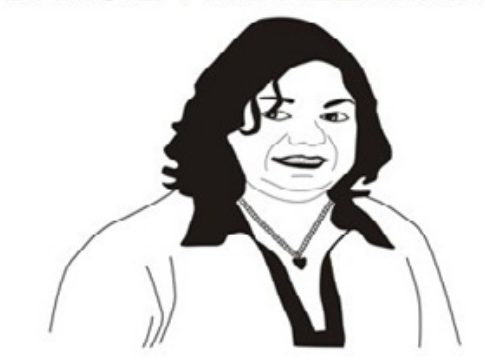

Inacreditável ável!!!

Mas não altera em nada a

qualidadevi devida

da população alação!!!

Figura 5. Meme Sanduíche-iche

Fonte: http://desciclopedia.org/wiki/Ruth_Lemos. Acesso em: 19 abr. 2018.

Devemos, contudo, antes de prosseguir na proposta de Shifman (2013) sobre Memes digitais na Web 2.0, fazer uma ressalva importante. Embora o termo Meme tenha sido difundido entre os usuários das redes sociais a partir da década de 2010, isso não significa que o termo não havia sido utilizado para tratar deste tipo de acontecimento na internet, conforme verificamos. Os estudos de Memética, descritos por Francis Heylighen e Klaas Chielens (2009) como "ciência teórica e empírica que estuda a replicação, propagação e evolução de memes" (HEYLIGHEN; CHIELENS, 2009, p. 2, apud SHIFMAN, 2013, tradução nossa), estudam o Meme a partir da perspectiva de Dawkins em diversos suportes para além da internet. Concordamos com Shifman (2013), contudo, que há uma série de problemas nessa abordagem, quando se trata de sua apreciação no meio digital: em primeiro lugar, por tratar o Meme de modo análogo a um vírus ou bactéria, propondo que seja disseminado como se fosse uma doença entre os usuários, porém desconsidera o papel da interpretação e da vontade dos atores sociais que participam da rede; em segundo lugar, por incorporar aspectos biológicos da teoria de Dawkins stricto sensu, isto é, tais perspectivas procuram por fenótipos, genótipos e códigos genéticos nas publicações; em terceiro lugar, há ainda abordagens que defendem que as pessoas são meros dispositivos que abrigam e espalham memes constantemente, como hospedeiros de uma doença. Em contraposição a essas concepções, Conte (2000 s/p, apud SHIFMAN, 2013, p. 12) afirma que "A disseminação dos Memes é baseada em agentes intencionais com poder de decisão: normas sociais, percepções e preferências são cruciais no processo de seleção memética.". 
Diante disso, consideraremos a leitura que a autora propõe sobre as características apontadas por Dawkins, porém levaremos em conta esta perspectiva que trata os usuários de Memes como atores em vez de vetores (cf. SHIFMAN, 2013). Também iremos demonstrar, em nossa análise, que o processo de interpretação de determinado enunciado é fundamental para que ele possa se caracterizar enquanto Meme.

De acordo com Shifman (2013, p. 9, tradução nossa), a respeito do trabalho de Dawkins,

Como genes, memes são definidos como replicadores que sofrem variação, concorrência, seleção e retenção. Em qualquer dado momento, muitos memes estão competindo pela atenção dos internautas; no entanto, apenas memes adaptados ao seu ambiente sociocultural se espalham com sucesso, enquanto outros se tornam extintos. $^{12}$

Diferentemente, portanto, de um viral (conteúdo que se espalha na internet), o Meme, necessariamente, deve possuir (ou a ter a capacidade de) variação, concorrência, seleção e retenção. Um conteúdo amplamente difundido não pode ser considerado um Meme se, por exemplo, não houver um deslocamento de sentido para outro contexto ou situação, seja por meio da transposição e/ou do diálogo entre textos, imagens ou ideologias, seja por meio da assimilação do conteúdo em outro contexto.

Como variação, entende-se que, para constituir um Meme, ele precisa se materializar de modo que haja a possibilidade de alteração de seu conteúdo ou contexto, isto é, um Meme só poderá ser assim chamado se seu enunciado ou contexto remeter e dialogar com sua matriz, fazendo sentido a determinado grupo. Shifman (2013) define concorrência e seleção a partir da maneira com que os Memes se adaptam às condições socioculturais dos meios em que se propagam - nos meios digitais, o próprio processo de formação destes Memes torna-se relevante e visível, fazendo com que os usuários interpretem antes de decidir replicá-los. Um determinado Meme só poderá ser estabelecido se as suas variações permitirem um processo de seleção entre suas instâncias que concorrem entre si nos diferentes contextos que se apresentam.

12 No original: "Like genes, memes are defined as replicators that undergo variation, competition, selection, and retention. At any given moment, many memes are competing for the attention of hosts; however, only memes suited to their sociocultural environment spread successfully, while others become extinct". 
Quanto à noção de retenção, a autora a relaciona com a noção de seleção de maneira dialética, de modo que uma determinada instância pode vir a ter um conjunto de características que não se adapte a determinados contextos socioculturais e, portanto, tenha menor adesão, variação e concorrência.

Se tomarmos o Meme citado no início desta sessão, "Sanduíche-iche" (figura 5), podemos observar estes conceitos de Shifman (2013): a variação pode ser observada quando as repetições que indicam a gaguejada da nutricionista, assim como seu retrato desenhado, são recontextualizados; como esta variação não é a única possível, haja vista ser possível adaptar o enunciado-fonte em outros contextos, assim como outras instâncias deste e de outros Memes estão em constante produção, temos, portanto, um processo de concorrência entre estes enunciados. A seleção e/ou retenção deste exemplo dependerá de fatores como o conhecimento prévio do enunciado-fonte, a importância maior ou menor para o fato da derrota brasileira e até mesmo a "vitória", isto é, a adesão, a outros Memes ou instâncias deste.

\section{Análise do Meme "Senhora"}

As diferentes ferramentas de geração de conteúdo multimodal e o modo de organização das redes sociais, que permite fácil compartilhamento de textos, imagens, gifs, dentre outros, possibilitaram uma expansão do potencial de construção do meme e alteraram, significativamente, sua forma de distribuição. Tendo isso em vista, propomos, nesta subseção, debater a constituição do Meme digital contemporâneo. Para isso, tomamos como exemplo o Meme "Senhora".

Tal Meme surgiu a partir de uma entrevista realizada com uma suposta servidora pública "fantasma", chamada Edinair, que, aparentemente, batia o ponto na Assembleia Legislativa de Goiás e ia embora. Ao ser questionada pela repórter, a funcionária saiu correndo enquanto a reportagem a perseguia repetindo: "Senhora, senhora, senhora...?"13. A partir de então, diversas instâncias do Meme foram publicadas a esse respeito, como podemos observar nas imagens 6 e 7 :

13 Disponível em: https://www.youtube.com/watch?v=GdxPG010fG4. Acesso em: 20 mar. 2017. 


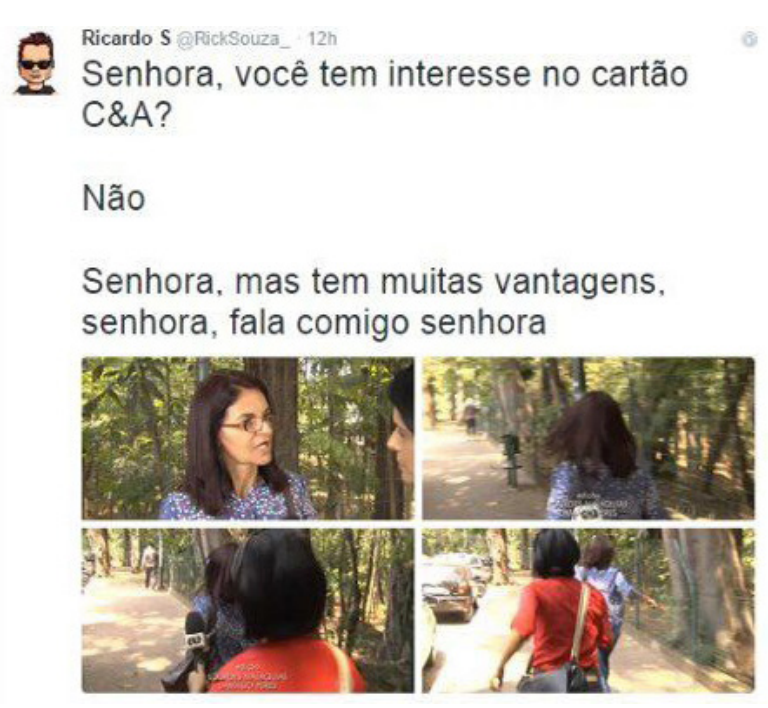

Figura 6. Senhora C\&A

Fonte: http://divadepressao.com.br/meme-do-dia-servidora-corre-ao-ser-flagradabatendo-o-ponto-e-indo-embora-sem-trabalhar/. Acesso em: 10 abr. 2017.

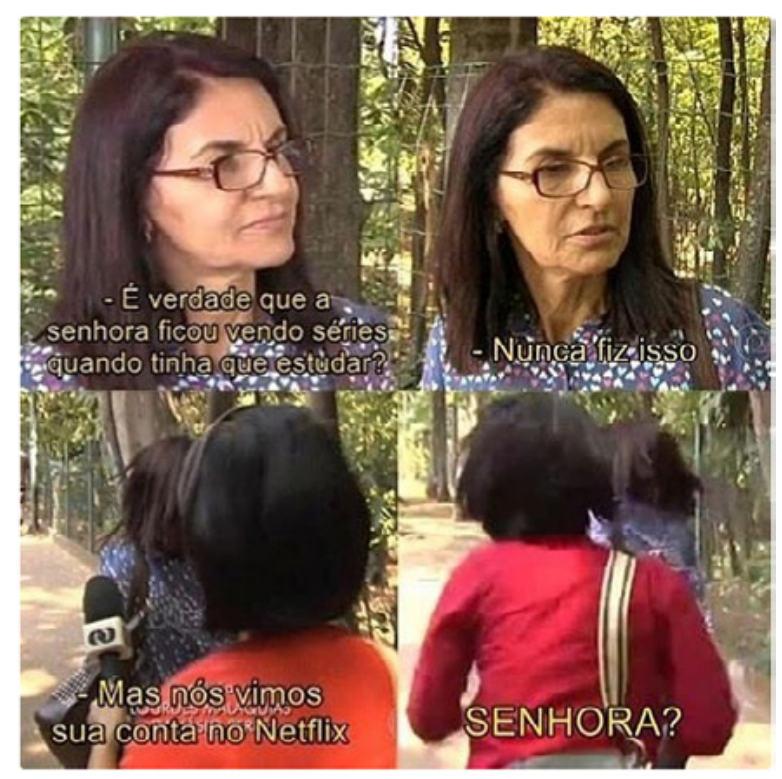

Figura 7. Senhora Netflix

Fonte: https://onsizzle.com/i/e-verdade-que-a-senhora-ficou-vendo-series-cuandotinha-1091287. Acesso em: 10 abr. 2017.

Nos dois exemplos, há uma mudança parcial do conteúdo e do contexto e manutenção do enunciado visual, ou seja, são mantidas as imagens da gravação em que a "Senhora" foge da repórter. Eles são, no entanto, deslocados para outro campo do conhecimento. 0 
primeiro diz respeito às propostas de cartão de crédito oferecidas por lojas como a C\&A, de modo a ressaltar a insistência dos representantes no sentido de alcançar seus objetivos. Já o segundo caso se relaciona com o tema da procrastinação dos estudos, em que a "senhora" passa a representar um "típico estudante" que, em vez de se concentrar em suas tarefas, acaba gastando todo o seu tempo assistindo a filmes e séries da plataforma de streaming Netflix. Quando observamos esses Memes em conjunto, podemos afirmar que o que dá coesão à sua constituição é a chave para a "fuga de algo". Do mesmo modo que a "Senhora" fugiu da repórter por não querer responder a uma pergunta que a colocaria em uma situação embaraçosa, constrangedora, perigosa, o primeiro Meme correlaciona a situação original do vídeo com uma possível situação constrangedora de perda de tempo por algo que não se quer fazer e pelos perigos que um cartão de crédito pode representar, ainda que em menor medida. Já o segundo Meme correlaciona a situação original com a situação embaraçosa de ter sido descoberto por algo socialmente condenável.

A correlação entre as situações é uma possível chave de interpretação de humor, pois, ao colocar no mesmo plano uma ação de corrupção e uma de procrastinação/fugir do cartão de crédito, os Memes constroem uma relação de equivalência entre as ações, gerando uma quebra de script (cf. RASKIN, 1987), o que justificaria, por um lado, sua produção com maiores níveis de concorrência e, por outro, a distribuição e o consumo com maiores chances de seleção.

Por outro lado, o mesmo Meme pode tomar contornos distintos e recortar apenas uma característica do enunciado-fonte, deslocando completamente o contexto e o conteúdo, como podemos observar em:

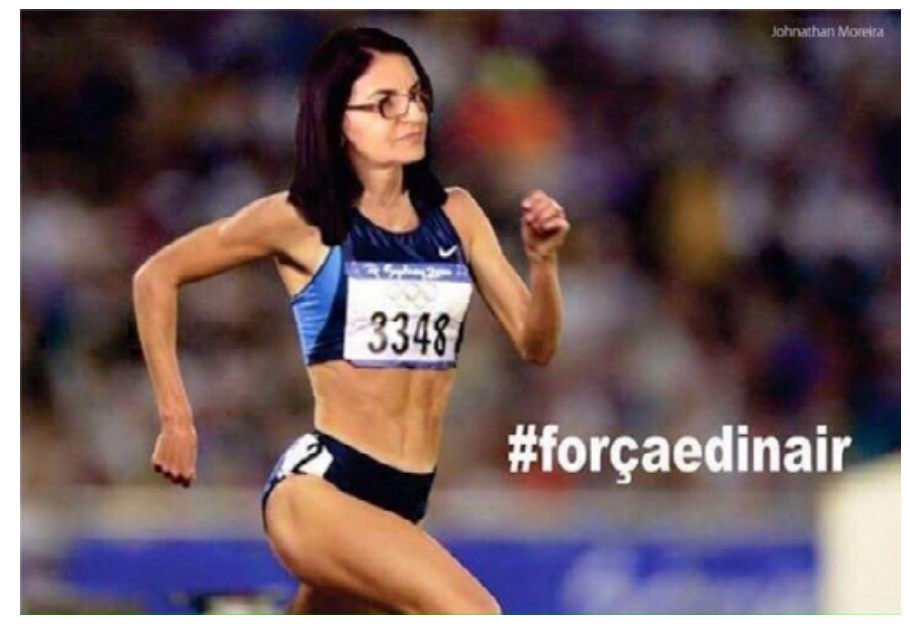

Figura 8. Senhora corredora

Fonte: http://pt-br.meme.wikia.com/wiki/Senhora/Galeria_de_Imagens. Acesso em: 10 abr. 2017. 
No exemplo acima, temos uma montagem do rosto da "senhora" em uma atleta profissional, provavelmente uma corredora olímpica. A característica de corrida, no entanto, toma outro rumo neste Meme, não mais somente à corrida para fugir de algo, mas também o de alguém que usa a corrida como esporte, aspecto reforçado, inclusive, pela hashtag "\#forçaedinair", apontando uma possível torcida para a "Senhora". A variação que temos neste Meme é feita a partir da aproximação de outra cena enunciativa, de modo que seu contexto sofre um apagamento. Já não importa qual atleta teve o corpo utilizado na montagem, tampouco sua origem. O deslocamento de contexto e do conteúdo pode ser, também, um desencadeador humorístico do Meme que remete diretamente ao textofonte.

Os exemplos que expusemos acima apresentam um deslocamento de conteúdo e de contexto para conhecimentos de ordem geral, que possuem uma partilha de conhecimento maior, isto é, possuem certa vantagem no que diz respeito às noções de concorrência e seleção que Shifman pontua. No entanto, a possibilidade de variação de um Meme também pode se dar de maneira mais particular em contextos mais restritos e com conteúdos relevantes para grupos menores, como em:

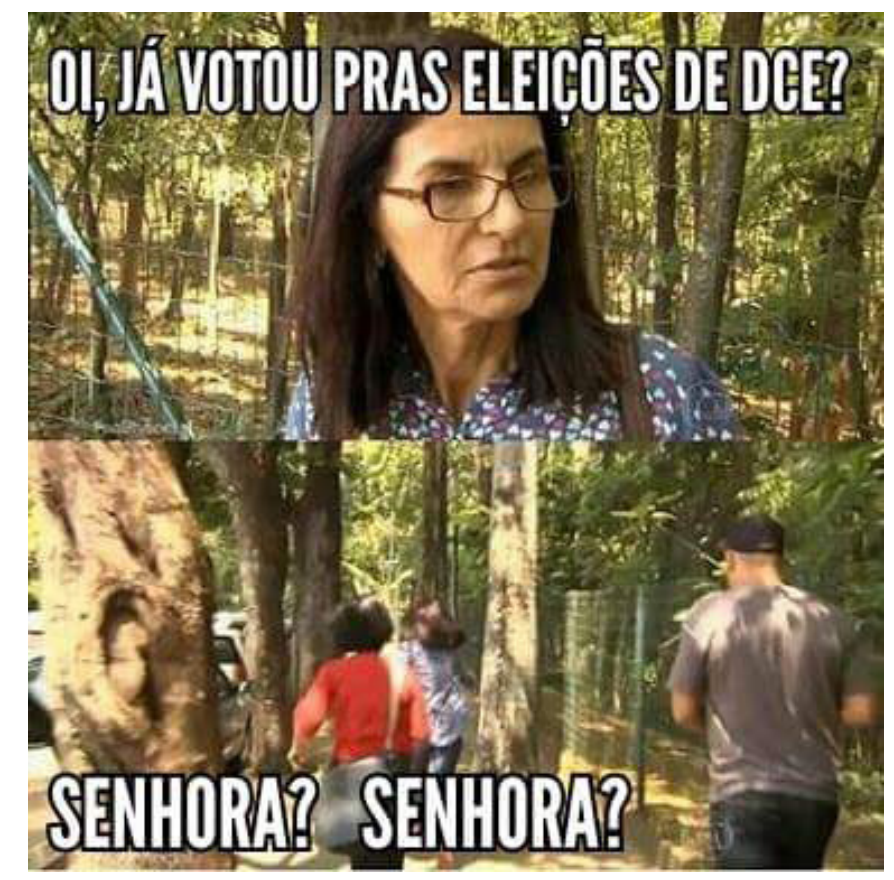

Figura 9. Senhora DCE

Fonte: Retirado de grupos de Facebook.

Dentre os Memes constituídos pelo enunciado-fonte da "Senhora", existirão aqueles mais "selecionados" pelos usuários, seja pelo seu apelo à determinada noção do senso comum ou pela capacidade de expressar uma representação condizente com a realidade 
sociocultural a partir de um dado posicionamento discursivo. No último exemplo, o conteúdo e o contexto aos quais o Meme se desloca possuem um campo mais restrito, uma vez que ele se volta exclusivamente a estudantes (e ex-estudantes) universitários que possuem (ou possuíram) algum contato com Diretórios Estudantis, Centros Acadêmicos etc. Como circulam em um campo menos vasto, é possível depreender que as relações com conhecimentos gerais desses Memes são menores e, portanto, possuem menor seletividade.

\section{Considerações finais}

Se temos os Memes como replicadores de determinado conteúdo, através da interação responsiva e dialógica (cf. SHIFMAN, 2013; BAKHTIN, 2003), só é possível concebê-los, além das características apontadas por Shifman, quando inseridos dentro de uma cadeia de gêneros, isto é, quando consideramos o enunciado-fonte que os originou e os diversos enunciados que o circulam e o complementam. O Meme em si não é capaz de produzir conteúdo, mas é a partir dele que se transformam os diversos enunciados anteriores em replicadores que tornam complexa a cadeia na qual está inserido. Em outras palavras, o Meme possui um valor responsivo e dialógico para com o texto-fonte ao qual se relaciona. Tal propriedade do gênero pode ser assim considerada, uma vez que, ao remeter ao discurso anterior, ele marca linguisticamente uma referência que possa indicá-lo - sem esta característica, a constituição do Meme enquanto tal fica prejudicada, se não anulada. Existe uma relação intertextual subjacente e necessária para se extraírem dados efeitos de sentido.

A constituição das variações deste Meme podem ser das mais virais às mais localizadas. Embora o termo tenha sido utilizado na internet de modo a demonstrar um determinado conhecimento partilhado, como ocorre com as já citadas "Lenny Faces", um Meme também pode atender a um universo particular de conhecimento. Uma turma da faculdade, por exemplo, pode produzir um Meme de algo que ocorreu em uma aula se conseguir atingir a retenção derivada da dinâmica entre seleção, variação e concorrência, de modo que o entendimento daquele enunciado será partilhado somente entre aqueles que possuem a chave de interpretação: o contexto e a referência ao enunciado-fonte.

\section{REFERÊNCIAS}

BAKHTIN, M. Questões de Literatura e Estética. São Paulo: Editora UNESP, 1993.

BAKHTIN, M. Gêneros do Discurso. In: BAKHTIN, M. Estética da Criação Verbal. São Paulo: Martins Fontes, 2003. p. 261-306.

CASTELLS, M. Networks of Outrage and Hope: Social Movements in the Internet Age Second Edition. Pollity Press: Malden, USA, 2015 [2012]. 
DAWKINS, R. The Selfish Gene. Oxford: Oxford University Press, 1979.

ELIAS, V. M. Quadrinhos e Leitura na mídia social digital: porque comentar é preciso. In: LINS, M. da P. P.; JÚNIOR, R. C. de S. Quadrinhos sob diferentes olhares teóricos. Vitória: PPGEL-UFES, 2014.

IBGE - Instituto Brasileiro de Geografia e Estatística. PNAD - Pesquisa Nacional por Amostra de Domicílios, 2015 [online]. Disponível em: https://ww2.ibge.gov.br/home/ estatistica/populacao/trabalhoerendimento/pnad2015/default.shtm\&gt. Acesso em: 08 ago. 2017

JABLONKA, E. Do Emoticon ao Meme - Evolução dos Símbolos na Comunicação Virtual. Acta Semiótica et Lingvistica, v. 17, ano 36, n. 1, p. 106-118, 2012.

KOBAYASHI, S. M. As Cadeias de Gênero do Meme "Bela, Recatada e do Lar". In: GONÇALVES-SEGUNDO, P. R. et al. Texto, discurso e multimodalidade. São Paulo: Paulistana Editora, 2017.

OLIVEIRA, L. V. Os Mitos Nórdicos segundo Neil Gaiman. Anu. Lit., v. 22, n. 1, p. 192-196, 2017.

RASKIN, V. Linguistic Heuristics of Humor: A Script-Based Semantic Approach. International Journal of the Sociology of Language 65, 1987.

SHIFMAN, L. Memes in a Digital Culture. Cambridge, MA: The MITpress, 2013

SOUZA-JUNIOR, J. Memes da Internet e a Produtividade Funcional: um argumento sistêmico-funcional e crítico-discursivo para a propagação dos fenômenos. Texto Livre: Linguagem e Tecnologia: Periódicos UFMG, v. 6, n. 2, p. 106-124, 2013. Disponível em: http://periodicos.letras.ufmg.br/index.php/textolivre. Acesso em: 08 ago. 2017. 